\title{
Characterization of Scale Formed in Drinking Water and Hot Water Pipes in the Taliouine Downtown-Morocco
}

\author{
Naima Hafid1*, M'barek Belaatar'1, Said Ben-Aazza1, Abdellah Hadfi'1, \\ Mohamed Ezahri², Ali Driouiche ${ }^{1}$ \\ ${ }^{1}$ Engineering Process Laboratory, Department of chemistry, Faculty of Sciences, Ibn Zohr University, Agadir, \\ Morocco \\ ${ }^{2}$ Materials and Environment Laboratory, Department of chemistry, Faculty of Sciences, Ibn Zohr University, \\ Agadir, Morocco \\ Email: ${ }^{*}$ hafidnaima@yahoo.fr
}

Received 17 June 2015; accepted 25 July 2015; published 28 July 2015

Copyright (C) 2015 by authors and Scientific Research Publishing Inc.

This work is licensed under the Creative Commons Attribution International License (CC BY).

http://creativecommons.org/licenses/by/4.0/

(c) (i) Open Access

\begin{abstract}
This paper presents the results of a comprehensive study of water scale found in water distribution system of Taliouine city in the south of Morocco. Physico-chemical properties of drinking water supplied to the city were evaluated. The data showed a high level of soluble salt in water. Concentrations were calcium 108 - $143 \mathrm{mg} / 1$, magnesium 80 - $96 \mathrm{mg} / 1$, bicarbonate 660 - $750 \mathrm{mg} / \mathrm{l}$ and hardness degree $660-690 \mathrm{mg} \mathrm{CaCO} / 3$. The water samples contain high amounts of minerals in the form of ions, especially the metals calcium and bicarbonate, which precipitated out and caused problems in water conducting or storing vessels like pipes. Scales were removed from the inside of two old pipes which transported drinking and hot water in the downtown of Taliouine city. Scale samples were investigated by XRF, XRD, SEM, DTA, TGA and SEM's analytical techniques. This study was able to identify scales formed in pipes of water distribution systems. It was found that water scale in this city contains $53 \%$ of calcium oxide and $43 \%$ of organic matter. The XRD and SEM results revealed that calcite was the main crystalline structure in drinking water scale. Nevertheless, scale deposited in hot water pipe is well crystalline with peaks corresponding mostly to aragonite (88\%) along with calcite $(12 \%)$. The thermal behavior of scale samples confirms that calcium carbonate was the main compound in the scale samples. Further studies are needed to find an efficient antiscale in drinking water of this city.
\end{abstract}

\section{Keywords}

Drinking Water, Scale, Characterization, Calcium Carbonate

\footnotetext{
${ }^{*}$ Corresponding author.
}

How to cite this paper: Hafid, N., Belaatar, M., Ben-Aazza, S., Hadfi, A., Ezahri, M. and Driouiche, A. (2015) Characterization of Scale Formed in Drinking Water and Hot Water Pipes in the Taliouine Downtown-Morocco. American Journal of Analytical Chemistry, 6, 677-686. http://dx.doi.org/10.4236/ajac.2015.68065 


\section{Introduction}

Water distribution system is a key to public health. Water distribution network cannot be considered as an inert system. Many reactions take place and solid deposit is formed on the walls of the water distribution equipments. These deposits cause serious technical and economic consequences such as total or partial obstruction of pipes leading to a decrease in flow rate; reduction of heat transfer, obstruction of the drains, thermal loss of effectiveness in boilers or heat exchangers, the filling of the filters, etc. [1]-[4]. In one word, the consequences of scale deposition are of different types: hydraulic, thermal and mechanical.

In this paper, we were interested to study water scale found in water distribution system in the downtown of Taliouine. This town is located on the border of the Anti-Atlas and High-Atlas, near the city of Taroudant, in the southern Souss region of Morocco. In fact, changing pipes transporting water from time to time is necessary because the scale formed in their interior wall decreased their diameter leading to poor performance. Hense, it is of vital importance to investigate this scaling problem in the water distribution system. Then, drinking water was firstly analyzed. Physico-chemical parameters analyzed include $\mathrm{pH}$, hardness, electrical conductivity, $\mathrm{Ca}^{2+}$, $\mathrm{Mg}^{2+}, \mathrm{K}^{+}, \mathrm{Na}^{+}, \mathrm{HCO}_{3}^{-}, \mathrm{NO}_{3}^{-}, \mathrm{SO}_{4}^{2-}, \mathrm{Cl}^{-}$and dry matter. Secondly, water scale samples were carefully collected from the inside wall of pipes that were recently removed. In this work, two pipes were used: one transported drinking water and the second transported hot water in a Moroccan steam bath. Several analytical techniques were used: X-ray fluorescence (XRF), X-ray diffraction (XRD), differential thermal analysis (DTA), thermogravimetry (TG) and Scanning electron microscopy (SEM) in order to identify and characterize scale samples.

\section{Materials and Methods}

\subsection{Drinking Water Sampling}

Sampling is the process of obtaining, containerizing, and preserving a potable water samples. In this work, water samples were collected in terminal tap each month in the downtown of Taliouine city. Taps selected for sample collection are supplied with water from a service pipe connected directly to the potable water network and are the most frequently used. The faucet of spigot was turned on at one-half to three quarters flow, and then the tap ran for approximately ten minutes to remove any stagnant water in the plumbing network. After this period, the flow was reduced to a trickle and samples were placed in PEHD bottles $(\mathrm{V}=5 \mathrm{~L})$. Observations and sample times were recorded on sampling sheets.

The Taliouine city is a Moroccan town located in Taroudant Province in Souss Massa Draa region. It is famous with a spice called Saffron. The weather in this city is semi-arid and water resources are limited. Summer is hot and temperature reached more than $40^{\circ} \mathrm{C}$.

The (Figure 1(a)) presents a general map showing the situation of the Souss Massa Draaregion in Morocco. The detailed map (Figure 1(b)) shows the location of Taliouine city in the Souss-Massa Draa region.

\subsection{Physico-Chemical Analysis}

\subsubsection{Drinking Water Analysis Methods}

Water parameters such as $\mathrm{pH}$, EC, Alkalinity, hardeness, ... fundamentals and characteristics elements were measured by standard methods of water analysis [5]. $\mathrm{pH}$, Temperature and Electrical Conductivity (EC) were measured immediately after samples collection using Xplorer GLX PASCO PS-2002.

Total hardness was determined using method of complexometric titration EDTA in which Eriochrome Black $\mathrm{T}$ (ErioT) is used as the indicator. The quantitative chemical analysis of sodium and potassium was performed, using a flame atomic absorption spectrometer VARIAN. Sulfate was determined by a gravimetric method in which sulfate is precipitated as barium sulfate. The absorbance of the barium sulfates formed is measured by a spectrophotometer and the sulfates ion concentration is determined by comparison of the reading with a standard curve. Nitrates content were determined by visible spectrophotometry. In the presence of sodium salicylate, nitrates give sodium paranitrosalicylate with yellow color which can be determined by colorimetric assay. Measurements were carried at the wavelength of $415 \mathrm{~nm}$. The titration of chloride concentrations in water samples was done by mercuric nitrate method.

\subsubsection{Water Scale Characterization Techniques}

Two removed pipes were used to collect the scale formed in their walls: a drinking water pipe and a hot water 


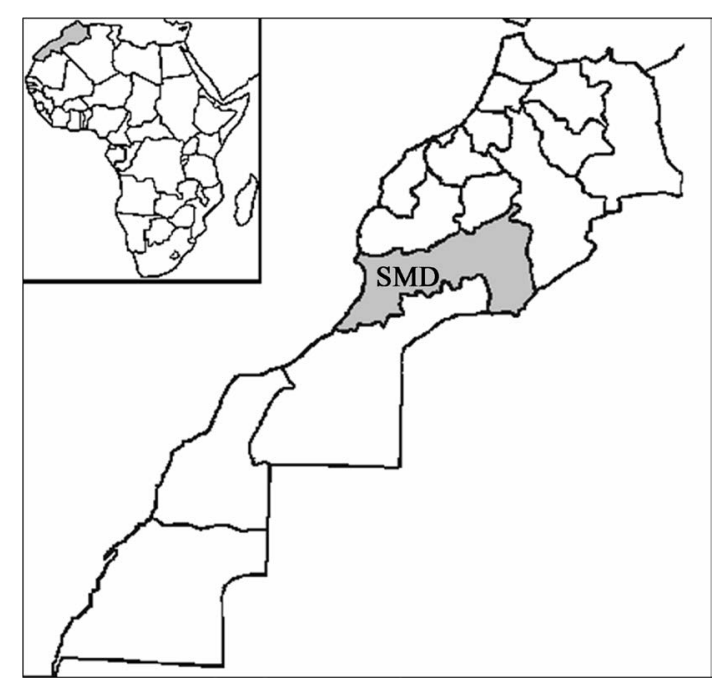

(a)

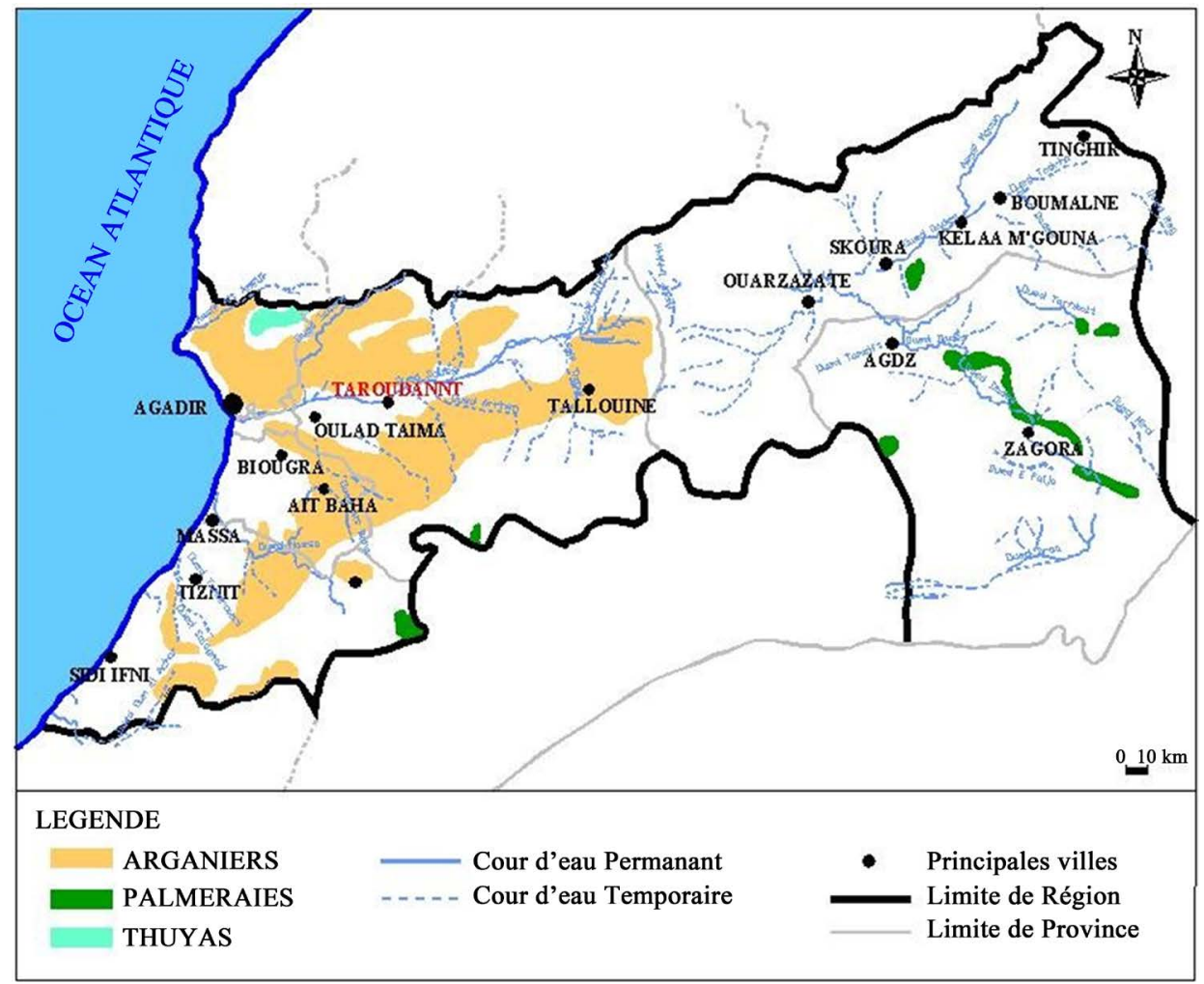

(b)

Figure 1. (a) General map showing the location of souss massa draa (SMD) region in morocco (in northern africa); (b) Detailed map showing the location of taliouine city in the souss-massa draa region of morocco.

pipe (in a Moroccan steam bath). Analytical techniques were used to identify and characterize the water scale samples [6]. Qualitative and quantitative chemical analysis was carried with PAnalytical Axios X-Ray Fluorescence Spectrometer. The scale morphology was investigated by FEI Quanta 200 scanning electron microscope (SEM). X-ray diffraction (XRD) was recorded using a PANalyticalX'Pert PRO diffractometer (Cu-K $\alpha$ radiation). Thermogravimetric analysis (TGA) and Differential thermal analysis (DTA) were carried out on a Shimadzu DTG-60 thermal analyzer, water scale samples were heated from $0^{\circ} \mathrm{C}$ to $820^{\circ} \mathrm{C}$ with a heating rate of $10^{\circ} \mathrm{C} \mathrm{min}^{-1}$. 


\section{Results and Discussion}

\subsection{Physico-Chemical Analysis of Drinking Water}

The physical and chemical properties of water samples including $\mathrm{pH}$, temperature, electrical conductivity, total hardness, calcium bicarbonate, magnesium, potassium, sodium, nitrate, sulfate, chloride and dry matter, were determined. The analytical results ranges are summarized in Table 1.

The chemical composition of water samples shows that $\mathrm{pH}$ values ranged from 7.3 to $7.8 \mathrm{pH}$ is one of the most important factors that servers as an index for the quality. It was found to be neutral to slightly alkaline. The electrical conductivity is relatively high. The EC average is $1.45 \mathrm{mS} / \mathrm{cm}$. The high level of the calcium, bicarbonates and hardness in the drinking water reflect the soil and rock nature in the region. It is constituted by clay-limestone (80\%) and sand-silt (20\%). As water moves through soil and rock, it dissolves minerals and holds them in solution like $\mathrm{Ca}^{2+}$ and $\mathrm{Mg}^{2+}$ which increase the degree of hardness (69 French degrees).

The water samples analysis show that anions concentrations are below permissible levels as per standards [7]. The calcium is the abundant major cation. Its concentration reached $143 \mathrm{mg} / \mathrm{l}$ which is out of acceptable limits [8]. It can enhance corrosion in water pipes. Magnesium and bicarbonate amount are also important and varied respectively from 80 to $96 \mathrm{mg} / \mathrm{l}$ and from 660 to $750 \mathrm{mg} / \mathrm{l}$. Those dissolved cations are the most common minerals that make water hard. Moreover, the values of sodium are high and ranged from 81 to $111 \mathrm{mg} / \mathrm{l}$ that increased water scaling in the presence of chloride which reaches $90 \mathrm{mg} / \mathrm{l}$.

During their movement, these waters give rise to the phenomenon of scaling. When waters were supersaturated, those dissolved salt were deposited in pipe wall and equipment in the form of scale. The increase of scale layer involved flow decreasing caused the seizing of the valves and taps. In hot water, it decreased the operating efficiency of pipes and caused serious failures of other equipment because of the low thermal conductivity of the solid layer.

\subsection{Water Scale Analysis}

\subsubsection{XRF Analysis}

The X-Ray Fluorescence (XRF) measurement identifies many chemical elements in the scale samples. In drinking water scale, the Calcium is the major component element besides Iron (Figure 2). It's followed by Magnesium, Silicon, Chromium then Sulfur, Oxygen, Chlorine, Phosphorus and trace amount of other elements such as Sodium, Barium, Zinc, Potassium, Titan, Manganese and Nickel.

The same in hot water pipe, XRF analysis of the scale formed inside show that the main element is calcium and the second element is iron (Figure 3). Then beside Iron, are Chromium, Silicon, Magnesium, Oxygen, Sulfur, Nickel and Strontium. Other elements are present in very low concentrations like Zinc, Barium, Copper,

Table 1. Physico-chemical analysis of drinking water in the downtown of Taliouine.

\begin{tabular}{ccc}
\hline Parameters & Minimum & Maximum \\
\hline $\mathrm{pH}$ & 7.3 & 7.8 \\
$\mathrm{~T}\left({ }^{\circ} \mathrm{C}\right)$ & 17 & 21 \\
$\mathrm{EC}(\mathrm{mS} / \mathrm{cm})$ & 1.4 & 1.5 \\
$\mathrm{HCO}_{3}^{-}(\mathrm{mg} / \mathrm{l})$ & 660 & 750 \\
$\mathrm{TH}\left(\mathrm{F}^{\circ}\right)$ & 66 & 69 \\
$\mathrm{Ca}^{2+}(\mathrm{mg} / \mathrm{l})$ & 108 & 143 \\
$\mathrm{Mg}^{2+}(\mathrm{mg} / \mathrm{l})$ & 80.3 & 96.5 \\
$\mathrm{~K}^{+}(\mathrm{mg} / \mathrm{l})$ & 11 & 14 \\
$\mathrm{Na}^{+}(\mathrm{mg} / \mathrm{l})$ & 81 & 111 \\
$\mathrm{NO}_{3}^{-}(\mathrm{mg} / \mathrm{l})$ & 5.7 & 7.4 \\
$\mathrm{SO}_{4}^{2-}(\mathrm{mg} / \mathrm{l})$ & 190 & 257 \\
$\mathrm{Cl}^{-}(\mathrm{mg} / \mathrm{l})$ & 70 & 90 \\
$\mathrm{Dry} \mathrm{matter}(\mathrm{mg} / \mathrm{l})$ & 900 & 1095 \\
\hline
\end{tabular}




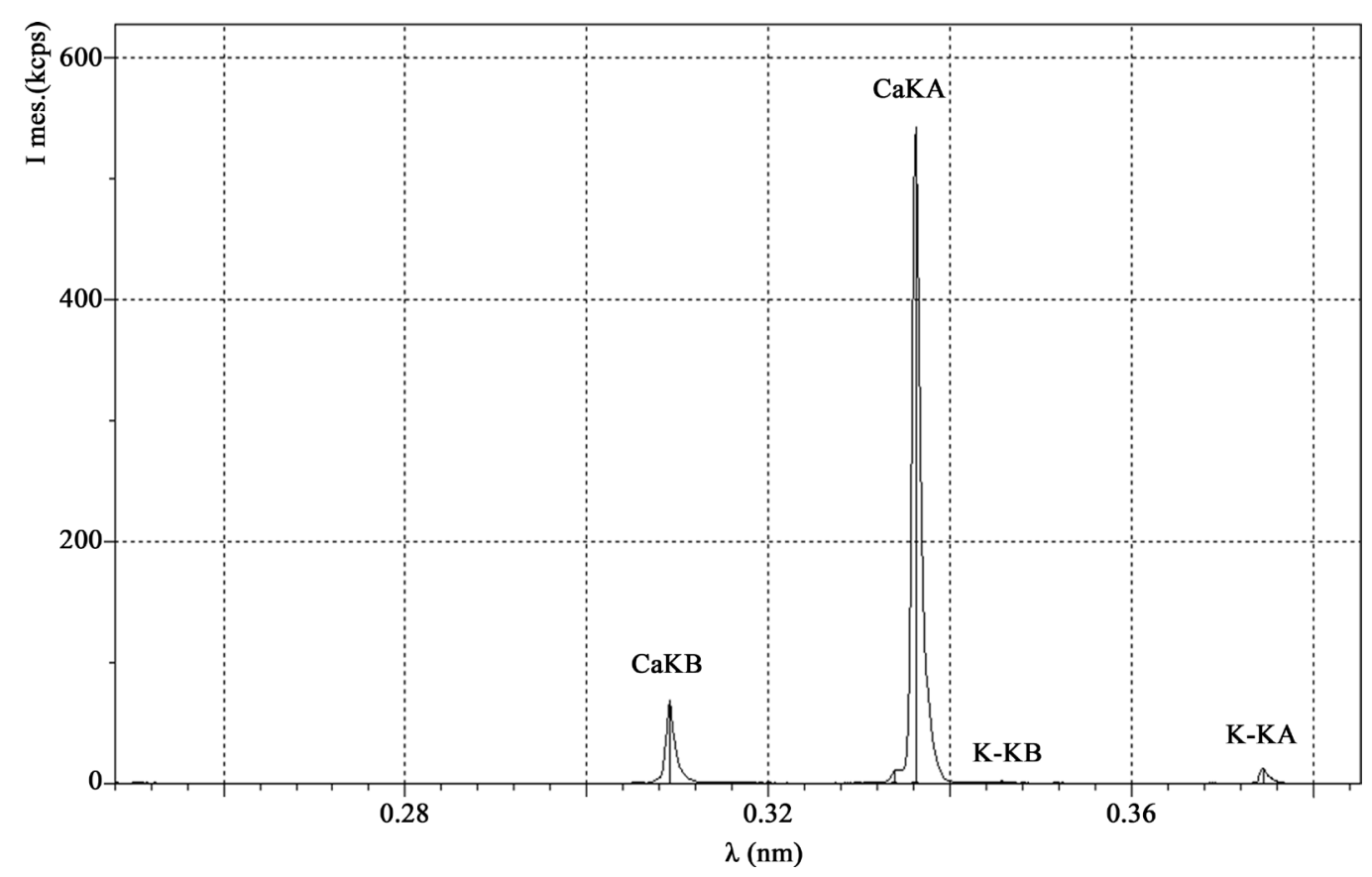

Figure 2. Examples of spectrums of XRF qualitative analysis of scale deposited in hot water pipe.

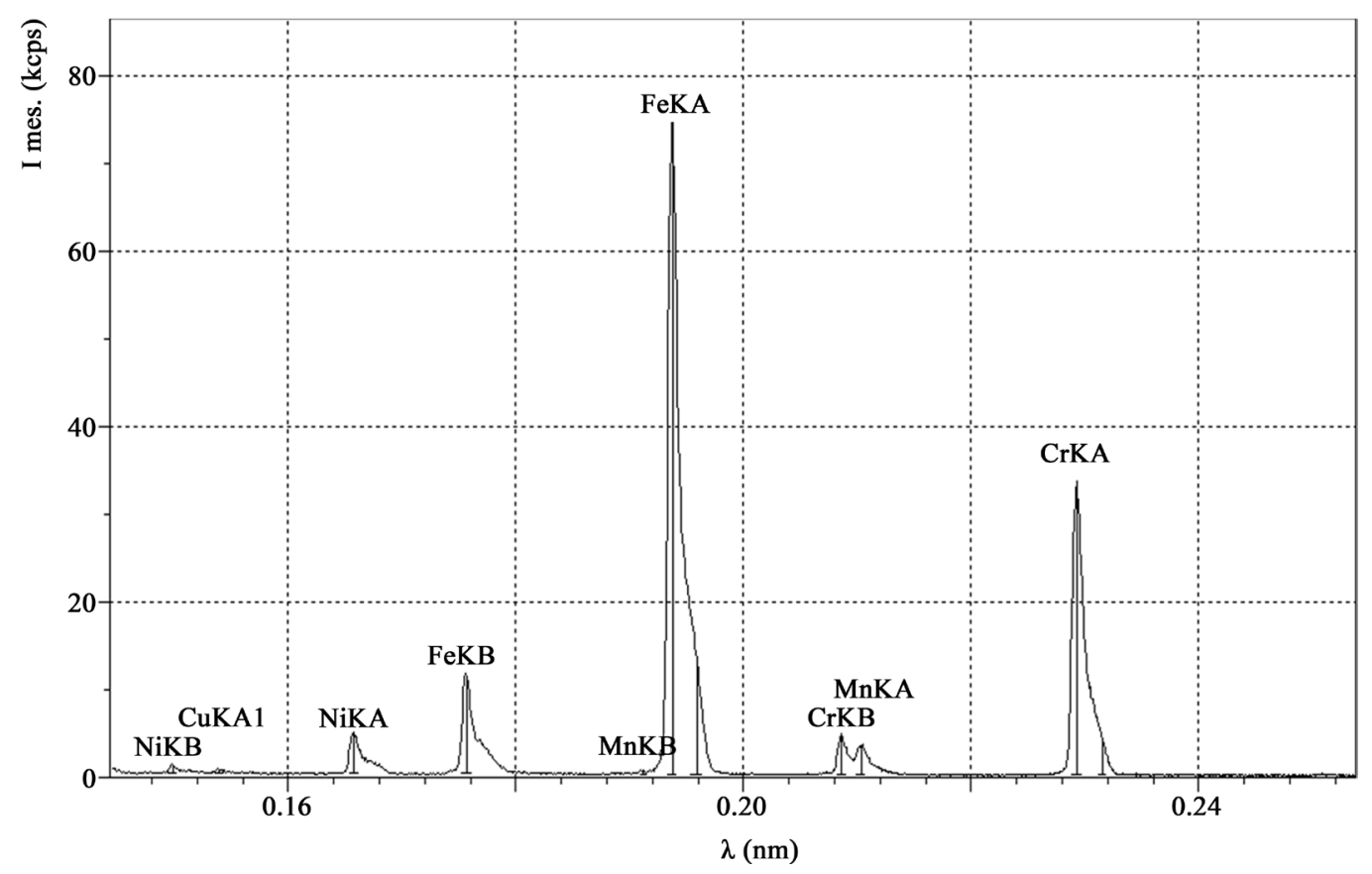

Figure 3. Examples of XRF profile of scale collected from hot water pipe.

Chlorine, and Sodium which can be mobilized into drinking water [9]. Peng reported that the deposits formed within drinking water distribution systems had the potential to retain inorganic contaminants [10].

Quantitative XRF analysis results are presented in Table 2. Scale samples were ignited at $975^{\circ} \mathrm{C}$ for $30 \mathrm{mn}$. The loss on ignition both in the scale collected in drinking water and hot water pipes is $44 \mathrm{wt} \%$. This percentage main that all scale samples contain a high level of organic materials.

The scale calcination produces calcium oxide $\mathrm{CaO}$ which is a very corrosive product [11]. This oxide constitutes $53 \%$ in the two types of scale. Other oxides were detected in very low quantities. Silica is found in water 
scale samples in a percentage of $1.15 \mathrm{wt} \%$ and $0.1 \mathrm{wt} \%$ respectively in drinking and hot water. Magnesium oxide (MgO) weight percent is more important in hot water scale (2.40 wt\%). Potassium oxide is not detected in all of samples. Other oxides like iron oxide $\mathrm{Fe}_{2} \mathrm{O}_{3}$, sodium oxide $\mathrm{Na}_{2} \mathrm{O}$ and phosphorus pentoxide $\mathrm{P}_{2} \mathrm{O}_{5}$ were detected in trace quantities $(<1 \mathrm{wt} \%)$. Chloride in drinking water scale $(460 \mathrm{ppm})$ is more important than in hot water scale (297 ppm).

Calcium carbonate is the predominant component of scale deposited from drinking water, not only in processes involving heat transfer but also in case without a temperature gradient as the transport of potable water [12].

\subsubsection{X-Ray Analysis}

Scale samples were analyzed by X-Ray diffraction (XRD) method to determine scale crystalline structure. In Figure 4 are the diffraction diagrams of drinking water scale (a) and hot water scale (b). The narrow peaks observed indicate high crystallinity of the scale samples. It is seen that samples scale present different crystalline structures.

X-ray diffraction results show two calcium carbonate polymorphs, the aragonite and calcite. Both minerals have their highest intensity peaks at different positions, and overall appearance of the two modes is different. In Figure 4(a), the peak at $2 \theta$ value of $29.4^{\circ}$ with a very high intensity indicates that only calcite was formed in drinking water pipe.

However, Figure 4(b) presents peaks of the two polymorphs with different intensities. It can be seen that aragonite has its greatest peak (111) at $2 \theta=26.25^{\circ}$ followed in order of intensity decreasing by peak at $46^{\circ}, 27^{\circ}$ and $33^{\circ}$ and several lesser peaks, while calcite has a peak of $104\left(29.4^{\circ}\right)$ booming (Figure 4(a)). It should be

Table 2. Quantitative chemical analysis of water scale by X-ray fluorescence (weight \%).

\begin{tabular}{ccc}
\hline Compound & Drinking water scale & Hot water scale \\
\hline Calcium oxide $(\mathrm{CaO})$ & 53.42 & 52.80 \\
Weight in ignition & 43.18 & 44.16 \\
Silica $\left(\mathrm{SiO}_{2}\right)$ & 1.15 & 0.10 \\
Iron oxide $\left(\mathrm{Fe}_{2} \mathrm{O}_{3}\right)$ & 0.79 & 0.03 \\
Magnesium oxide $(\mathrm{MgO})$ & 0.75 & 2.40 \\
Alumina $\left(\mathrm{Al}_{2} \mathrm{O}_{3}\right)$ & 0.20 & 0.00 \\
Phosphorus pentoxide $\left(\mathrm{P}_{2} \mathrm{O}_{5}\right)$ & 0.18 & 0.14 \\
Sodium oxide $\left(\mathrm{Na}_{2} \mathrm{O}\right)$ & 0.14 & 0.10 \\
Sulfur trioxide $\left(\mathrm{SO}_{3}\right)$ & 0.00 & 0.22 \\
Potassium oxide $\left(\mathrm{K}_{2} \mathrm{O}\right)$ & 0.00 & 0.00 \\
\hline
\end{tabular}

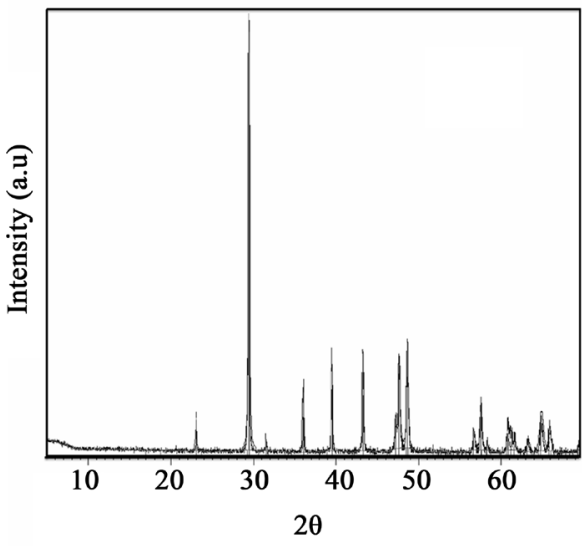

(a)

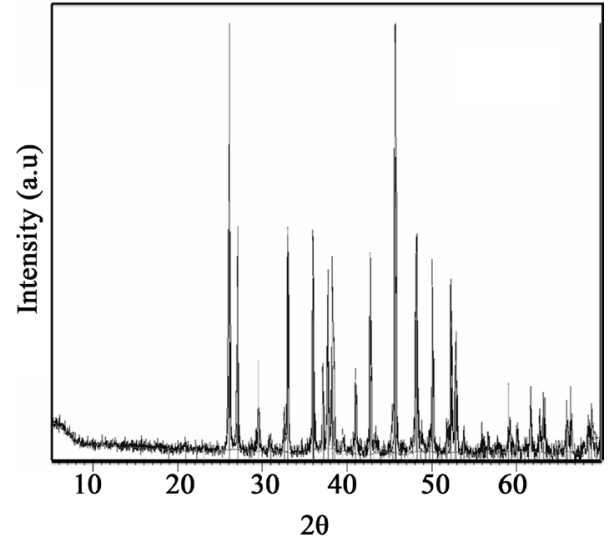

(b)

Figure 4. XRD of water scale formed in: (a) drinking water pipe and (b) hot water pipes. 
noted that the calcite peak at $26^{\circ}, 25^{\circ}$ decreased in intensity in hot water scale (Figure 4(b)). Thus comparison of the most intense peaks allows using the aragonite peak $221\left(2 \theta=46^{\circ}\right)$ as an indicator of the abundance of aragonite. Another approach that provides a more intuitively acceptable result is to compare the calcite peak 113 at $2 \theta=43^{\circ}$ and the aragonite peak 221 at $2 \theta=48^{\circ}$ vertices. In this case, the hot water scale is a mixture of calcite and aragonite which generates various high peaks, facilitating rapid approach glance. The aragonite percentage is found to be $88 \%$ and the calcite is $12 \%$ in the hot water scale. In Figure 4(b), only the intensities corresponding to the aragonite form have great intensity. The increasing of temperature in pipe transporting hot water favors the formation of aragonite which is metastable at normal ambient temperatures. Those two crystalline forms of $\mathrm{CaCO}_{3}$ calcite and aragonite both natural and synthesized are the most studied. Their transformations have been the subject of extensive and varied research, both experimentally and theoretically [13]-[19]. Their structure has been also studied in different conditions by a variety of methods [20]-[28].

\subsubsection{SEM Analysis}

In many natural water, when the concentration of calcium carbonate exceeds the saturation level, its precipitation is of concern. The crystallization of $\mathrm{CaCO}_{3}$ gives birth to agglomerate of particles which present different morphologies depending on the conditions. The SEM micrographics in Figure 5 show different $\mathrm{CaCO}_{3} \mathrm{Crystal}^{-}$ lization in scale samples. In drinking water scale, the calcium carbonate shows regular shape structure. The crystals are rhombohedra-like and cubical (Figure 5(a)).

While, in hot water pipes, the needle-like aragonite crystals are observed in mixture with calcite crystals (Figure 5(b)). The amount of calcite crystal decreases and aragonite crystal dominated. Conditions were favorable for the formation of elongated shape crystals of aragonite [29]. Due to the crystal morphology we assume that the needle-like crystals refer to aragonite and the rhombohedric to calcite. It is reported by literature that calcium carbonate can precipitate in three types of crystal structures [30]: aragonite, calcite and vaterite. These forms are reversible under some conditions [31] [32] affecting the mineralogy of the $\mathrm{CaCO}_{3}$ formation [11]. Basically, the solubility data show that calcite scale formation increases with a decrease in $\mathrm{CO}_{2}$ gas partial pressure, increase in temperature and $\mathrm{pH}$, and decrease in the salinity of the solution [33] [34]. In other words, Ca$\mathrm{CO}_{3}$ scaling is a function of ionic strength of the solution, temperature, $\mathrm{pH}$, calcium-cation concentration, and bicarbonate anion concentration [35]-[38].

\subsubsection{GTA and DTA Analysis of Water Scale}

Thermogravimetric analysis was used as a complementary to DTA as it provides continuous weight variation data relatable to DTA peaks. The curves obtained are given in Figure 6. The DTA thermograms exhibit one endothermic peak with the maximum at $790^{\circ} \mathrm{C}$. It shows the decomposition process of calcium carbonate which starts slowly at about $350^{\circ} \mathrm{C}$. This decomposition is accompanied of a mass loss of about $43 \%$ and $44 \%$ respectively for a drinking water scale and a hot water scale. This is in reasonable agreement with XRF results above and the literature value of $44 \%$ attributed to the decomposition of $\mathrm{CaCO}_{3}$ into $\mathrm{CaO}$ with the loss of carbon dioxide [39]-[42].

\section{Conclusions}

The physico-chemical analysis of drinking water in the Taliouine downtown shows that it contains high amounts
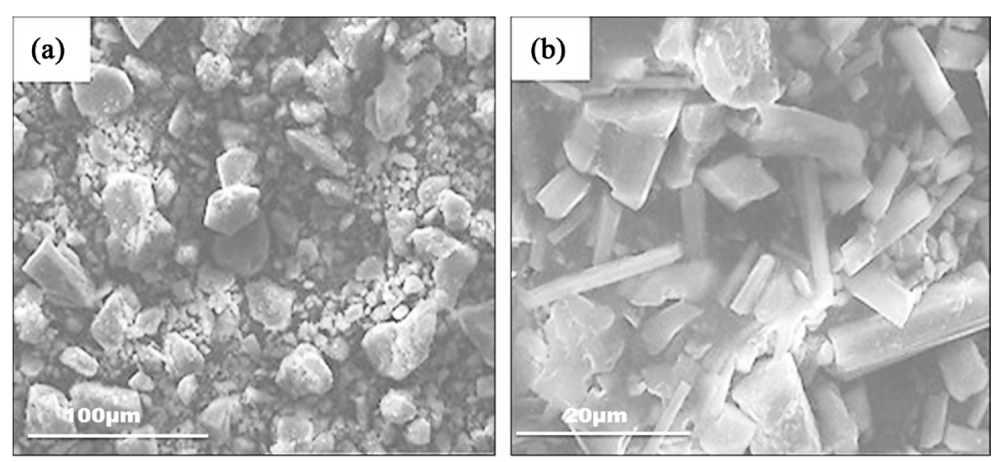

Figure 5. SEM photograph of scale in: (a) drinking water scale and (b) hot water scale. 


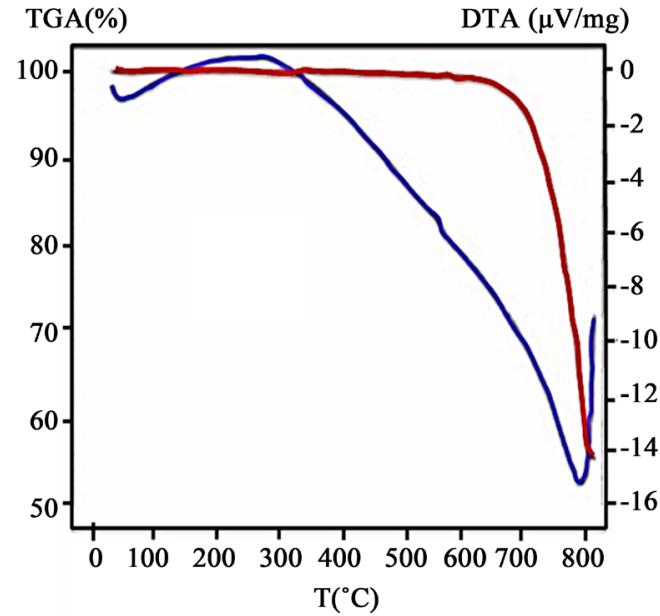

(a)

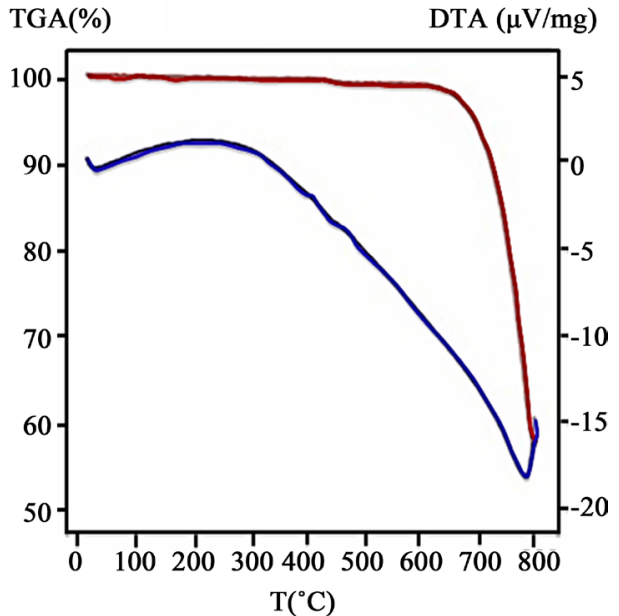

(b)

Figure 6. Thermogravimetric and differential thermal analysis curves of scale samples in: (a) drinking water scale and (b) hot water scale.

of minerals ions especially calcium cation and bicarbonate anions. These minerals ions precipitate and cause problems in both drinking and hot water piping. Such ionic deposits leading to the formation of scale on the inside of the pipes are harmful because, first, they lead to a gradual clogging of pipes and, secondly, they promote and facilitate the implementation and development the biofilm microorganisms.

The combination of XRF, XRD, SEM, GTA and DTA has been very useful to identify and characterize the water scale deposited in pipes that were transporting drinking water and hot water. Analytical results show that scale samples are rich in calcium oxide (53 wt\%). Loss on ignition which is roughly equal to the amount of organic matter present was found to be $43 \mathrm{wt} \%$. DTA and GTA curves confirm those results. The XRD results reveal that scale deposited in hot water pipe is well crystalline with peaks corresponding mostly to aragonite (88\%) along with calcite (12\%) which are confirmed by SEM images. We can conclude that water scale samples deposited in the two removed pipes are calcium carbonate which is related to the movement of the calco-carbonic balance.

\section{References}

[1] Larson, T.E. and Buswell, A.M. (1942) Calcium Carbonate Saturation Index and Alkalinity Interpretations. Journal of the American Water Works Association, 34, 1967-1979.

[2] Ras, H.S. and Ghizellaoui, S. (2012) Determination of Anti-Scale Effect of Hard Water by Test of Electrodeposition. Procedia Engineering, 33, 357-365. http://dx.doi.org/10.1016/j.proeng.2012.01.1215

[3] Behera, R.K., Das, P.S., Das, R. and Das, N.N. (2013) Physicochemical Characterizations and Sorption Properties of Deposited Scale from Hard Water. Indian Journal of Chemical Technology, 20, 95-100.

[4] Tyusenkov, A.S. and Cherepashkin, S.E. (2014) Scale Inhibitor for Boiler Water Systems. Russian Journal of Applied Chemistry, 87, 1240-1245. http://dx.doi.org/10.1134/S1070427214090080

[5] Rodier, J., Legube, B., Merlet, N. and Brunet, R. (2009) L’analyse de l'eau. Paris, France.

[6] Woodward, V.P., Williams, R.C. and Amjad, Z. (2010) Chapter 21: Analytical Techniques for Identifying Mineral Scales and Deposits. In: Amjad, Z., Ed., The Science and Technology of Industrial Water Treatment, USA, 425-445. http://dx.doi.org/10.1201/9781420071450-c21

[7] NM 03.7.001 (2006) Moroccan Standard for the Quality of Water for Human Consumption. Official Bulletin No. 5404, March 16.

[8] WHO (2004) Guidelines for Drinking-Water Quality. 3rd Edition, Vol. 1, World Health Organization, Geneva.

[9] Renner, R. (2008) Pipe Scales Release Hazardous Metals into Drinking Water. Environmental Science and Technology, 42, 4241. http://dx.doi.org/10.1021/es087143m

[10] Peng, C.-Y., Gregory, V.K., Richard, L.V., Andrew, S.H., Melinda, J.F. and Steve, H.R. (2010) Characterization of Elemental and Structural Composition of Corrosion Scales and Deposits Formed in Drinking Water Distribution Systems. Water Research, 44, 4570-4580. http://dx.doi.org/10.1016/j.watres.2010.05.043 
[11] Gagnon, J.P. (2007) X-Ray Fluorescence Spectrometry: Development of Effective Fusion Procedures for Lime Products. JCPDS-International Centre for Diffraction Data, 76-82.

[12] Andritsos, N., Kontopoulou, M., Karabelas, A.J. and Koutsoukos, P.G. (1996) Calcium Carbonate Deposit Formation under Isothermal Conditions. The Canadian Journal of Chemical Engineering, 74, 911-919. http://dx.doi.org/10.1002/cjce.5450740614

[13] Leeuw, N.H.D. and Parker, S.C. (1998) Surface Structure and Morphology of Calcium Carbonate Polymorphs Calcite, Aragonite and Vaterite: An Atomistic Approach. The Journal of Physical Chemistry B, 102, 2914-2922. http://dx.doi.org/10.1021/jp973210f

[14] Zhou, G.T., Yu, J.C., Wang, X.C. and Zhang, L.Z. (2004) Sonochemical Synthesis of Aragonite-Type Calcium Carbonate with Different Morphologies. New Journal of Chemistry, 28, 1027-1031. http://dx.doi.org/10.1039/b315198k

[15] Gerard, Y. (1987) Etude expérimentale des interactions entre déformation et transformation de phase, Exemple de la transition Calcite-Aragonite. Thèse de Doctorat, Université de Rennes I, Rennes.

[16] Zhou, G.-T. and Zheng, Y.-F. (1998) Synthesis of Aragonite-Type Calcium Carbonate by Overgrowth Technique at Atmospheric Pressure. Journal of Materials Science Letters, 17, 905-908. http://dx.doi.org/10.1023/A:1026444118595

[17] Amjad, Z., Kleptsanis, G. and Koutsoukos, P.G. (2002) Precipitation and Crystal Growth of Calcium Carbonate in the Presence of Acrylic Acid Copolymers. 15th International Symposium on Industrial Crystallization, Sorrento, 15-18 September 2002, 267.

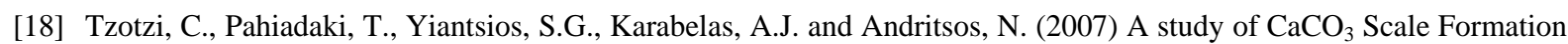
and Inhibition in RO and NF Membrane Processes. Journal of Membrane Science, 296, 171-184. http://dx.doi.org/10.1016/j.memsci.2007.03.031

[19] Wray, J.L. and Danniels, F. (1957) Precipitation of Calcite and Aragonite. Journal of the American Chemical Society, 79, 2031-2034. http://dx.doi.org/10.1021/ja01566a001

[20] Ogino, T., Suzuki, T. and Sawada, K. (1987) The Formation and Transformation Mechanism of Calcium Carbonate in Water. Geochimica and Cosmochimica Acta, 51, 2757-2767. http://dx.doi.org/10.1016/0016-7037(87)90155-4

[21] Santomauro, G., Baier, J., Huang, W. and Pezold, S. (2012) Formation of Calcium Carbonate Polymorphs Induced by Living Microalgae. Journal of Biomaterials and Nanobiotechnology, 3, 413-420. http://dx.doi.org/10.4236/jbnb.2012.34041

[22] Wang, H., Alfredsson, V., Tropsch, J., Ettl, R. and Nylander, T. (2013) Formation of $\mathrm{CaCO}_{3}$ Deposits on Hard Surfaces-Effect of Bulk Solution Conditions and Surface Properties. ACS Applied Materials and Interfaces, 5, 4035-4045. http://dx.doi.org/10.1021/am401348v

[23] Kiaei, Z. and Haghtalab, A. (2014) Experimental Study of Using Ca-DTPMP Nanoparticles in Inhibition of CaCO 3 Scaling in a Bulk Water Process. Desalination, 338, 84-92. http://dx.doi.org/10.1016/j.desal.2014.01.027

[24] Liu, D., Dong, W., Li, F., Hui, F. and Lédion, J. (2012) Comparative Performance of Polyepoxysuccinic Acid and Polyaspartic acid on Scaling Inhibition by Static and Rapid Controlled Precipitation Methods. Desalination, 304, 1-10. http://dx.doi.org/10.1016/j.desal.2012.07.032

[25] Jada, A., Ait Akbour, R., Jacquemet, C., Suau, J.M. and Guerret, O. (2007) Effect of Sodium Polyacrylates Molecular Weight on the Crystallogenesis of Calcium Carbonate. Journal of Crystal Growth, 306, 373-382. http://dx.doi.org/10.1016/j.jcrysgro.2007.05.046

[26] Medeiros, S.K., Albuquerque, E.L., Maia Jr., F.F., Caetano, E.W.S. and Freire, V.N. (2006) Structural, Electronic, and Optical Properties of $\mathrm{CaCO}_{3}$ Aragonite. Chemical Physics Letters, 430, 293-296. http://dx.doi.org/10.1016/j.cplett.2006.08.133

[27] Zhou, G.T., Yao, Q.Z., Ni, J. and Jin, G. (2009) Formation of Aragonite Mesocrystals and Implication for Biomineralization. American Mineralogist, 94, 293-302. http://dx.doi.org/10.2138/am.2009.2957

[28] Smyth, J.R. and Ahrens, T.J. (1997) The Crystal Structure of Calcite III. Geophysical Research Letters, 24, $1595-1598$. http://dx.doi.org/10.1029/97GL01603

[29] Young, C.I. and Byung-Gap, C. (1998) Experimental Validation of Electronic Anti-Fouling Technology with a Plate Heat Exchanger. Heat Transfer, 6, 197-201.

[30] Mantilaka, M.M.M.G.P.G., Karunaratne, D.G.G.P., Rajapakse, R.M.G. and Pitawala, H.M.T.G.A. (2013) Precipitated Calcium Carbonate/Poly(Methyl Methacrylate) Nanocomposite Using Dolomite: Synthesis, CHARACTERIZATION and properties. Powder Technology, 235, 628-632. http://dx.doi.org/10.1016/j.powtec.2012.10.048

[31] Stănăşel, O., Iovi, A., Kristmannsdottir, H. and Stănăşel, I. (2006) Physical-Chemistry Studies on Geothermal Waters and Scale Formations. Revue Roumaine de Chimie, 51, 179-185.

[32] Borch, T., Camper, A.K., Biederman, J.A., Butterfield, P.W., Gerlach, R. and Amonette, J.E. (2008) Evaluation of Characterization Techniques for Iron Pipe Corrosion Products and Iron Oxide Thin Films. Journal of Environmental 
Engineering, 134, 835-844. http://dx.doi.org/10.1061/(asce)0733-9372(2008)134:10(835)

[33] Westin, K.-J. and Rasmuson, A.C. (2005) Crystal Growth of Aragonite and Calcite in Presence of Citric Acid, DTPA, EDTA and Pyromellitic Acid. Journal of Colloid and Interface Science, 282, 359-369. http://dx.doi.org/10.1016/j.jcis.2004.03.029

[34] Coto, B., Martos, C., Peña, J.I., Rodriguez, R. and Pastor, G. (2012) Effets in the Solubility of $\mathrm{CaCO}_{3}$ : Experimental Study and Model Description. Fluid Phase Equilibria, 324, 1-7. http://dx.doi.org/10.1016/j.fluid.2012.03.020

[35] Kamari, A., Gharagheizi, F., Bahadori, A. and Mohammadi, A.H. (2014) Determination of the Equilibrated Calcium Carbonate (Calcite) Scaling in Aqueous Phase Using a Reliable Approach. Journal of the Taiwan Institute of Chemical Engineers, 45, 1307-1313. http://dx.doi.org/10.1016/j.jtice.2014.03.009

[36] Antonogiannakis, E., Tzagkaraki, E. and Demadis, K.D. (2013) Use of a Pilot Scale Heat Exchanger-Cooling Tower System for the Evaluation of Mineral Scale Inhibitors. International Journal of Corrosion and Scale Inhibition, 2, 255-268. http://dx.doi.org/10.17675/2305-6894-2013-2-4-255-268

[37] Goodman, W.H., Godfrey, M.R. and Miller, T.M. (2011) Scale and Deposit Formation in Steam Assisted Gravity Drainage (SAGD) Facilities. Nalco Company, Naperville.

[38] Sarin, P., Snoeyink, V.L., Bebee, J., Kriven, W.M. and Clement, J.A. (2001) Physico-Chemical Characteristics of Corrosion Scales in Old Iron pipes. Water Research, 35, 2961-2969. http://dx.doi.org/10.1016/S0043-1354(00)00591-1

[39] Menzri, R. and Ghizellaoui, S. (2012) Chronoamperometry Study of the Inhibition of Groundwater Scaling Deposits in Fourchi. Energy Procedia, 18, 1523-1532. http://dx.doi.org/10.1016/j.egypro.2012.05.169

[40] Nicolet, J.P. and Vernet, J.P. (1965) Analyse thermique différentielle: Application au problème des carbonates. Bulletin de la Société Vaudoise des Sciences Naturelles, 69, No.318, Lausanne.

[41] Faust, G.T. (1950) Thermal Analysis Studies on Carbonates, I-Aragonite and Calcite. The American Mineralogist, 35, 207-224.

[42] Bischoff, J.L. and Hole, W. (1969) Temperature Controls of Aragonite-Calcite Transformation in Aqueous Solution. The American Mineralogist, 54, 149-155. 